\title{
An Autoethnography of Child Artists in Tamil Dance Reality Television Production
}

\author{
P Sithara Venkatesh *
}

\section{Abstract}

Reality Television shows that revolve around the lives of children have become popular to audiences of all ages, which is evident in their success across diverse channels and various demographics (Palmer, 2013). With the increase in the number of reality shows and child participants in them, emerges a critical need of questioning the power of those in authority and are incharge of production over the powerless group (the children) who aren't of an age to legally possess the right to consent on their work, but have become the primary focus of almost every aspect of media commercialisation. An analysis of the conditions and effects of child participation in reality shows is extremely complex as it is difficult to make a child share his/her experience with others. It is also true that the history of children's daily experiences are extremely difficult to trace, since children themselves have had little or no access to those public forms of expression (Holland, 2004).

This paper is an autoethnographic study that explores Tamil dance reality television's child artists during the period 2008-2020.The bodily performances of the dance reality television's child artists and crew are studied by focusing on the intersections of body and space and with them developing in this context the concept of Biopolitics, as advanced by Michel Foucault (1979). The qualitative study covers a sample of 8 dance reality shows in five

\footnotetext{
* PhD Research Scholar, Department of Journalism \& Communication, University of Madras, India; sitharavenkatesh@gmail.com
} 
different Tamil channels with a focus on 12 child artists and how they spend their everyday lives in the shooting sets, rehearsal studios and other media production spaces. The researcher, being an insider in the reality television programmes, as a freelance floor director and coordinator for more than ten years now, provides this paper a significant leverage of the same and uses methods of memory work and self-reflexive writing along with indepth interviews.

Keywords: Autoethnography, Child Artist, Tamil Television, Dance Reality Production, Biopolitics.

\section{Introduction}

This paper is an autoethnographic account that attempts to question and understand the things that are not visible in the first sight of the reality television production practices involving child participants. The performative spaces and its everyday happenings that form the production culture and the intangible practices that define the productions are put under analysis with the help of Foucault's Biopolitics (1979) as the framework. This qualitative study covers a sample of 8 dance reality shows in five different Tamil channels with 12 child artists with a focus on how they spend their everyday life in the shooting sets, rehearsal studios and other media production spaces. Being an insider in reality television programmes, as a freelance floor director and coordinator for more than ten years now, this paper takes leverage of the same.

The National Commission for the Protection of Child Rights in 2011 had issued guidelines on the participation of child artists in media related productions with special concerns to reality television and advertisements. It said "Regulating working hours, prohibiting inappropriate roles and providing for adequate supervision are all required concerns today". Do you think the media organisations implement these regulations, or put them into everyday practice while using child artists in their shows? As these basic regulations stay unimplemented, there are unnoticed disastrous issues involved. Notably the use and abuse of adult power over children that tend to be framed in terms of accountability within the public 
realm (Venkatesh, 2020) needs critical attention. There is however, a missing link in this nexus, which centres on the role of civil society in framing social and moral discourse of adult-child power relations. The sociocultural context of the debate is often lost in the public discourse of condemnation and denial. Several studies have been made on the effects of representations on TV viewers, as audiences. But none of them represent children. Globally there are only a few studies on children working in reality television. Not to forget the scholars who have covered the common and critical issues of child artists in television like Lucia Palmer, 2013; Christopher C. Cianci, 2008; Hilary Levey, 2010; Ebony M. Roberts, 2004 and Alecia T. Devantier, 2011 and the Indian scholars who majorly concentrate on the educational, physical and health parameters of the child artists, like Sharmistha Bhattacharjee, 2014 (Sophisticated Work Done by Children: is Child Labour: An Overview of Children Working in Industries).

There are not many critical studies on understanding the child artist's day-to-day life, their psychological status, mental and emotional stress, effects of stardom, public imagery and other significant critical dimensions of childhood. This paper is an initiative to bring the real reality of the child artist's participation in reality television programs by confronting their bodily practices in their performative spaces. This study is a part of my ongoing Ph.D. thesis and specifically focuses on the significance of the seldom used autoethnography as an academic identity. As Ellis and Bochner says, this study of autoethnography is "dealing with the messy and ambiguous, but real dimensions of human experience" (2016).Without tracing the everyday experiences of the child artists in the reality television production sets, I could only give you unrealistic fancy stories about how talented they are. Bringing to light the unseen side of media productions is next to impossible using traditional methods of research. There is an utmost necessity for autoethnographic researches that allow personal narrative to enlighten the behind-the-screen happenings. As Danahay says "the ability to transcend everyday conceptions of selfhood and social life is related to the ability to write or do autoethnography. This is a postmodern condition. It involves a rewriting of the self and the social" (Reed-Danahay, 1997, p.4). 


\section{Autoethnography and its Origin}

It is noted, that the term autoethnography has been in use for more than 40 years now (originated by Hayano, 1979) and has become the term of choice in describing studies of a personal nature (Ellis, 2004; Ellis \& Bochner, 2000) to enhance and elaborate the social and cultural practices. But until today many communication research methods texts do not discuss autoethnography at length or at all (e.g., Lindlof \& Taylor, 2011; Merrigan \& Huston, 2010; R. Rubin, A. Rubin, Haridakis, 2009). Especially in Tamil Nadu, it is considered as a research method only in fields like anthropology and is always criticised when handled by a media and communication student (out of my experiences in presenting papers in national and international conferences). But the fact is that autoethnography is more than just a method that could be used by any researcher irrelevant of their disciplines. An autoethnography "lets you use yourself to get to culture" (Pelias, 2004).

This paper is an exploration of the autoethnographic methodology which allows me to write in my own personalized style, drawing on my experiences in the reality television space with the child artists to extend understanding about a societal phenomenon. It also helps me discuss the significance of using autoethnography as a layman's tool to enhance one's own personal experience in understanding and critiquing the cultural experience.

The term autoethnography originated in the 1970s. Anthropologist Karl Heider (1975) used the term autoethnography to describe the practice of members belonging to a community giving an account of their culture. Even though Heider coined the term, David Hayano (1979) is credited as being the first to use this term in a similar manner to which we use it now, with the researcher being in and of the group being studied (Ellis, 2007). Goldschmidt (1977, p.294) called all ethnography "self-ethnography" in that ethnographic representations privilege personal beliefs, perspectives, and observations. Autoethnography comprises both ethnography, in which the realist concurrence and objective observer position of standard ethnography have been criticised and questioned, and a postmodern autobiography, in which the notion of the coherent individual self has been similarly called into question. The term has 
double sense - referring either to the ethnography of one's own group or to autobiographical writing that has ethnographic interest. Thus, either a self (auto) ethnography or an autobiographical (auto) ethnography can be signalled by "autoethnography" (Reed-Danahay, 1997, p. 2).

In the 1990s, "autoethnography" became a method of choice for using personal experience and reflexivity to examine cultural experiences, especially within communication (Adams, Ellis and Jones, 2017). The most cited and accepted explanation of the term autoethnography is from Ellis and Bochner's which says "autoethnography is considered as a research method that uses personal experience (auto) to describe and interpret (graphy) cultural texts, experiences, beliefs, and practices (ethno)" (Ellis, 2004; Jones, 2005). Sparkes highlights the personal connotation that this method carries and denotes it as "highly personalized accounts that draw upon the experience of the author/researcher for the purposes of extending sociological understanding" (Sparkes, 2000, p. 21). As autobiography plays a significant role in the emergence of autoethnography, Ellis and Bochner suggests that "Autobiographical research methods had gradually become increasingly known as 'autoethnography' (2000, p.742) and they define autoethnography as "autobiographies that self-consciously explore the interplay of the introspective, personally engaged self with cultural descriptions mediated through language, history, and ethnographic explanation".

\section{Legitimising Autoethnography in my Research}

I had intolerable doubts on how my personal experience and interest would justify a $\mathrm{PhD}$ research and I left myself vulnerable on every occasion of my paper presentation as I was bombarded with questions of consent, value and credibility of my work from other faculties and research scholars. Few of the often made questions that I was catapulted were: How do you handle being biased, are you sure that you are taking a neutral stand? What is the validity? What kind of authenticity can we expect? What is your eligibility criteria for being an autoethnographer? How did you handle your judgemental perspectives? Where is the community or nativity here in the reality television research? The 
answers to all these questions were unveiled as I discovered autoethnography as a methodology.

In 2010 when I joined as an internee in a private television channel as part of the completion of my final year B.Sc. Visual Communication degree, I realised my inclination towards taking control and coordinating reality productions. I slowly learnt the art of floor management along with which I was also expected to do script writing, costume - property co-ordinations, artist management and contestant handling. Show after show I was working on all these responsibilities until a point of time when I realised that my working style was very apt and appreciated by the adult participants and was completely strange and bewildering to the child participants. My fast pace work style; hurrying tone; arrogance in maintaining punctuality; usage of abusive languages in-order to get the work done on time; were all completely sane, normal and more than satisfactory to the television industry. In-fact I was considered highly competitive and was appreciated by many celebrities and crew members for getting the work done at any cost and on the right time (which saved a lot of production money for my boss). My pride and prejudice blocked my vision until a day when I saw a consistently proven, promising and very talented 6 years old child contestant in my dance reality show perform unusually pathetic. The child had never failed the expectations kept on him during all the previous episodes (shoots) unlike that day which bothered almost everyone and he ended up in the danger zone (fortunately saved by his previous performances). When his parents intervened on the reason behind his ill performance, he wept and said

"I was keeping cool and working on my costumes until Sithara dhidhi came and shouted at me to get ready right away to get on to the stage. As I hurried up to the stage to perform, I heard her shout bad words at others and I started panicking and went blank during my performance"

This incident shook me to the reality of the system I was part of. This was technically to be seen as a major complaint. But it came to me as a request to not use filthy words when the child is on-stage. This was one of the incidents that made me realise the nature of media power that I was a part of. I had started worrying about the 
nature of the job that I was doing and the more difficult part was to think of the child participants who were, unknowingly struggling in the world of adults, without much awareness and appropriate consent. The power that I thought I possessed over my job was inadvertently making the children completely powerless victims. Though it has been years since the self-realisation took place, I am still unsure about completely understanding children because their worlds are far different from grown-ups. The usual research methods of content analysis or case study failed to achieve even the initial level of progress in my study. And there was no method that allowed me to understand the child artists and make optimum use of my access into their private lives that I had because of my previous working experiences with them. It was rightly said that, "In research that seeks to discover personal experience, there is a unique relationship between researcher and participant" (Clandinin \& Connelly, 1994).

As an insider in the production house, I had greater privilege and access towards understanding the children and only autoethnography allowed me to make use of my own experiences and observations into the study. As Ellis had mentioned, "the use of self-observation as part of the situation studied to selfintrospection or self-ethnography as a legitimate focus of study in and of itself" (Ellis, 1991, p. 30) is the most genuine way to bring out the reality. But self-observation and reflexive writing also involves enormous guilt and confession in the process and I had to ensure that I am not breaking researcher subject boundaries by taking over-advantage of the power and access I had among the participants. It took days for me to put myself into the shoes of the children to understand their thought processes during their exposures to sudden fame as they appear on-screen.

Being a part of the conventional academic society which only teaches us the traditional research methods, I have always felt uncertain about my approach to the research area in traditional ways of quantitative methods. I have repeatedly in regular intervals asked my supervisor if I was allowed to do my research in the first person narrative. I often had the doubt if our education system would really value a research that has my own thoughts and experience in it. Clearly, I am not alone in my uncertainty 
regarding my knowledge and its presentation (Wall, 2006). "For many, especially for women being educated as researchers, voice is an acknowledgment that they have something to say" (Clandinin \& Connelly, 1994, p. 423). However, breaking the conventional belief of using a positivist approach and third person narrative, provided an overwhelming confidence in my research. This method paved the way for a confident researcher in me. The potential power of questioning the unquestionable entities in the society has flushed in a greater inspiration to do a critical research to bring change in the society.

As my supervisor insists, the engagement with a research topic should arise with the researcher being personally involved or affected. In which case the study has intense interest, powerful reflections, passionate concerns and a strong voice raised for justice. Unlike the positivist approaches and the quantitative methods, intense introspection and complete immersion in the subject is completely possible through autoethnography. This paper is written with personal emotions, subjective biases and irrationality. There is confession and guilt intertwined through this journey. I make no attempts to bring neutrality or generalisation to my study. I genuinely use methods of memory work and selfreflexive writing along with in-depth interviews to record the plights of children working as child artists in reality shows of Tamil television.

"Writing in such a personalised and emotional style challenges the old orthodoxy of researcher as neutral, 'objective' and textually absent, leaving the autoethnographer vulnerable to charges of being 'irrational, particularistic, private, and subjective, rather than reasonable, universal, public, and objective" (Greenhalgh, 2001,p. 55)

"Writing is a way of knowing, a method of inquiry" (Richardson, 2000) and learning to write in new ways does not take away one's traditional writing skills any more than learning a second language reduces one fluidity in one's first language. To write my experiences means to observe and record many intangible practices behind the screen and its effects on the mental and emotional states of the children. 


\section{Reality Television and the Elevated Ordinariness}

Reality television as a genre has become an accepted and durable entertainment format, watched by millions globally in a variety of media forms according to Penzhorn and Pitout (2006). When the current scholars are more worried about the social networking platforms and digital labour, the reality television and its concerns remain away from the critical analysis under the banner of television studies which is considered the traditional media today. "The conventional is uncritically enjoyed, and the truly new is criticized with aversion" (Benjamin, 1969). To start with a definition that Hill (2005) had given: "reality television is a catch-all category that includes a wide range of television programs about real people. Sometimes called popular factual television, reality television is located in the border territories, between information and entertainment, document and drama" (Hill, 2005). This definition raises a number of questions such as: Where do we find a wide range of real reality shows these days? If a show calls itself a reality show, where are the real people in it and where is the factuality? Lack of appropriate answers to these questions and the bombardment of unrealistic reality into the minds of the people in the name of entertainment, brings a crisis on understanding the alarming effects of reality television. In which case, what is a reality show? It is clear that

"It represents an unabashedly commercial genre united less by aesthetic rules or certainties than by the fusion of popular entertainment with a self-conscious claim to the discourse of the real. This coupling is what has made reality television an important generic form for a range of institutional and cultural developments" (Murray and Ouellette, 2004).

It is obvious that the reality shows have gone far beyond portraying the real reality and are mostly doing a testing job of the contestants. They trigger directly or indirectly the participant's mental and physical endurance capacities and build the channel's TRP out of it. They also manage to keep the audience in a passive state of control. Considering the television channels as institutions of fascism, I am in agreement with what Benjamin said, "Fascism sees its salvation in giving these masses not their right, but instead 
a chance to express themselves" (Benjamin, 1969). By roping in ordinary people in reality shows, the media organisations have discovered new ways of developing viewership to their channels and have managed to keep the participants in an illusion that they are gifted to receive an opportunity such as this for a lifetime. But the ordinary participants are unaware that, by elevating their ordinariness the channel is only using them as a commercial product.

"Elevated Ordinariness" was the term used by Penzhorn and Pitout in 2006 to describe reality television. This genre promotes and portrays itself as a factual reality which is free from manufacturing labour and that it sustains by enhancing the lives of the ordinary people. In spite of the intangible power structures and hegemonic discourses, this fabricated genre of television is well received by the audiences. Reality television is a genre that has become an accepted and durable entertainment format, watched by millions globally in a variety of media forms (Penzhorn and Pitout, 2006). The popularity of Reality TV has been an economic game changer for the creative industries (Andrejevic, 2008; Biressi\& Nunn, 2013; Hill, 2005).

These kinds of institutional practices with intangible intentions victimise the child participants to an alarming level.

"Reality Television programmes that revolve around the lives of children and teenagers have become popular to audiences of all ages, which is evident in their success across diverse channels and various demographics" (Palmer, 2013).

The use of children in television may also amount to exploitation by television networks and advertisers, reflecting a voyeurism that brings more viewers and shoppers (Shmueli, 2015). In the following paragraphs I discuss and try to understand what children undergo under the expectations of the camera.

\section{Children in front of the camera}

Child artists! Can we call them a glamorized version of child labour or a colourful version of child exploitation? Are child artists unnoticed victims of the audience's selfish entertainment? Are 
education and physical health the only concerns that children in television have? Are they not mentally affected? Have they had a normal childhood like others? Isn't participating in an adult's world (reality television) psychologically hazardous to them? Who is responsible for their victimisation? - is it the parents who push their kids to earn money and popularity? Or the viewers who like them so much and yet do not bother to think even once about the conditions in which they work? Or the capitalist institutions that exploit them for their own benefits? The fame and status of being a celebrity may be envied upon from a common man's perspective but the real celebrities have a tough time protecting and maintaining their privacy and personal life from the limelight of the media.

When adults themselves find it a tough job to be a celebrity, consider children who become the non-consenting victim of their parents prejudice. Fame is understandably alluring for the young participants of reality programs, but it comes with several drawbacks. Patricia Holland, an author who is a well renowned scholar in the field of studying children questions the children's public imagery. "What sort of exploitation is involved when children, the most powerless group in society, are pictured for the pleasure and delight of adults who potentially have total control over them?" (Holland, 2004: xii)

When children are made to perform in front of the camera, they undergo a major transformation from their real self to the persona of a celebrity under the immense pressure. The physical and mental transitions they undergo is very complicated and seldom researched upon. I would like to detail an example of a teenager (now 19 yrs.) who participated in two dance reality shows at the age of 10 and was a finalist in the first show and a winner in the next. Michael (Name changed to protect the identity of the individual) was known to me as I was floor managing and assisting the show in which he participated. The child was peculiar and out of the box with his dance styles replicating Michael Jackson and was applauded and rewarded by the crew and the judges for the same. But many opted not to notice his peculiarity out of the camera zones. The child had completely contradicting natures on and off the stage, and In front of and behind the crew members. 
He stayed humble and obedient onscreen at the same time, arrogant and dominant off the screen. I understood by talking to his father that his family was poverty-ridden, living in a hut house and Michael was their only source of hope. Under these circumstances and the sudden fame through reality television, the child considered himself a celebrated hero. During my informal interviews with him, I heard him utter the word "craze" very often. He kept insisting that he had crazy girl fans wherever he goes and that people are crazy about his dance revolution. He considered himself the centre of attraction on all the occasions. Having known all his successful endeavours, I went deeper into his life to understand the truth. It was true that his talents fascinated the world, but it survived only for a temporary period of time. The fanfollowing theories that he always mentioned were only partially true. The fact was that the child was a school dropout and had exaggerated self-boasting habits. He was undergoing depression two years after his participation in the reality show due to lack of opportunities.

The short period of reality show participation had built up very big castles in his dreams which replaced his living reality. He was not able to earn big, neither through his talent nor through a normal job as he did not have adequate education to back him up. After so many years of his appearance on television, even today he only talks about international invites that are offered for his talent and well-off producers ready to invest in his dance album.

\section{Stardom and Public Image}

The exposure of camera leaving them exposed to a mass viewership has its own devastating impact on the children. "The viewers of the pictures become joint authors of the stories through the pleasures of recognition and re-use. Even the most personal forms of experience and the tales we tell about ourselves are partly shaped by public imagery and publicly available narratives. These pictures become our pictures, these stories our stories. This is imagery in use." (Holland, 2004: 3)

The instant fame and celebrity status of the child artists are usually admired and appreciated by the society. But the deep effects of the 
same are seldom known by the parents or the children themselves. The parents consider an opportunity from a television channel as an opportunity out of hardships and their children as the means to reach luxury from the current struggling state. The children were made to deprioritise their education without a second thought. Seven child artists out of the twelve respondents in my study were school dropouts. Their reason for leaving education was unequivocally their participation in reality television programs. To establish thoughts of the child artists on education and schooling, I quote what Simon (name changed to protect identity) had said during an interview:

"I used to manage to attend my classes once a week. But it would feel like I am on an alien planet among complete strangers. I couldn't follow with my subjects and syllabuses. I landed up being an outstanding student (sarcastically spoken). Instead of wasting my time by standing outside the classes, I chose to increase my focus and rehearsals for the upcoming competitive rounds."

Habib (name changed to protect identity), another child artist, never accepted that he had given up schooling. Whenever the judges enquired about his schooling he used give a prideful story about how the school teachers and the principal celebrated him and how famous he was at school. But listening to his boastful stories and out of inquisitiveness I had to enquire further to know that he had quit school as soon as he made his first successful appearance onscreen. Another respondent Joe (name changed to protect identity) who is currently an assistant choreographer in the film industry has learnt to positively accept his troubled time with reality shows:

“However hard I studied I wasn't able to catch-up with my classmates. I was always lagging behind. I felt I was appreciated more for the dance inside me and was never even acknowledged for my efforts in my studies. I failed to realise my existence in my classroom. I was physically present and mentally absent in my classes. The minimal marks that I scored never affected me at a point of time. That was when I realised that studies are not my cup of tea. But dance is. I regretted this decision after my failure in the initial dance reality shows. I 
even had suicidal thoughts as I don't have any backup to fall back to. But now being the youngest assistant choreographer and having a bright journey ahead, I feel all the struggles were worth it. It's just that I have lost a few years in depression. "

Patricia Holland (2004) in her book "Picturing Childhood: The Myth of the Child in Popular Imagery" analyses the inescapability of routine imagery and its effective creation of continuities in societal perceptions of children. Holland conceptualizes "public imagery" (p.3) as similar to a database that is accessible from anywhere and anytime: certain images are present across media forms and create a simplistic "pictorial vocabulary" (p. 4). According to Holland, these repetitive concepts and stereotypes are ever-present in an individual's mind, and are referred to in any process of meaning formation. The precipitous escalation of a child artist in front of a camera has deep rooted emotional and psychological strains inside. Not considering any of the child's stunted growth, the media organisations strive to have the children objectified for their own commercial purposes. I compare this situation of the child artists with what Walter Benjamin mentioned in his article "The work of Art in the Age of Mechanical Reproduction."

"The feeling of strangeness that overcomes the actor before the camera, as Pirandello describes it, is basically of the same kind as the estrangement felt before one's own image in the mirror. But now the reflected image has become separable, transportable. And where is it transported? Before the public. Never for a moment does the screen actor cease to be conscious of this fact. While facing the camera he knows that ultimately he will face the public, the consumers who constitute the market. This market, where he offers not only his labour but also his whole self, his heart and soul, is beyond his reach. During the shooting he has as little contact with it as any article made in a factory" (Benjamin, 1969)

The child artists in reality television are merely turned into a sellable product. They are deeply sub-consciously made to believe that they are profited, illuminated socially and benefited financially by the exposure of reality televisions. In the early 1920's, the Hungarian Marxist Georg Lukacs drew on Marx's theory of 
commodity fetishism to suggest how this process through which the subject is emptied of meaning and agency, turned into a 'thing', can be extended into the culture and philosophy of a capitalists society in general. He called this reification (Wayne, 2009: 187).

\section{Biopolitics and Child Artists}

"Socially the child star is a much more complex figure, generating emotive reactions and blurring the lines of distinction between childhood and adulthood, naivety and experience, and vulnerability and power. As the site of such complexity, the child star is clearly of cultural significance in our society" (Connor, 2008: xii).

To understand and analyse the real plight of child artists in a complex social structure of Tamil reality television, we will have to look using the filters of Foucault's framework of Biopolitics. For Foucault, life cannot be understood in terms of biological forces or determinants that exist outside of political processes. Instead, life must be understood as both an object and effect of political strategies and technologies. Biopolitics, he argues, refers to a historical transformation and development, beginning in the 17th century, whereby the sovereign right to seize, repress, and destroy life is complemented by a new form of power that aims to develop, optimize, order, and secure life. As Foucault say's

"What we are dealing with in this new technology of power is not exactly society (or at least not the social body, as defined by the jurists), nor is it the individual body. It is a new body, a multiple body, a body with so many heads that, while they might not be infinite in number, cannot necessarily be counted. Biopolitics deals with the population, with the population as a political problem, as a problem that is at once scientific and political, as a biological problem and as power's problem." (1976:245).

Foucault, through the concept of bio politics, was already pointing out in the seventies what, nowadays, is well on its way to being obvious: "life" and "living being" are at the heart of new political battles and new economic strategies (Lazzarato, 2002). Understanding the effects of child participation in reality television 
is a complex initiative. I also have the responsibility to explain why it is so. This is an area of research where neither the victim understands the victimisation nor the parents who force them into exploitation accept it. The desire to instant fame, stardom and elevated economic status blinds the parents to foresee the amount of dangers that they confer on to their younger generations. The framework of biopolitics is best suited to analyse and understand how the bodies of children participating in reality shows are functioning in the production spaces and how they are being treated by the media organisations and other adults in the shooting sets; out of which they develop deep psychological traumas, insecurities and false consciousness.

A closer scrutiny of the biopolitical production practices clearly indicates that media practices have failed to maintain equality among their workers. Spaces such as caravans, channel meeting halls, higher official's personal cabin, production console and food serving areas provide instances of how child artists behave and are treated by the surrounding adults including their parents in such spaces. Every individual body "speaks" without necessarily uttering. The functioning of bodies in a particular manner conveys more information than the words that they speak. This leaves us space to understand and interpret the body politics. In the production sets, where child artists participate, there are a number of intangible practices involving the crew, child artists and their parents. The very gesture of a child getting on the stage is to be keenly observed. Taking the case of Tamil dance reality show, I have witnessed the majority of the child artists setting their right foot on stage and taking a bow to the audience, making a gesture of prayer and touching the feet of the judges before every performance.

"Every word, every gesture constitutes an act, and acts must be understood according to their purpose, their results, and not merely in terms of the person speaking and acting, as though he could somehow express or 'externalize' his reality and sincerity. More exactly, words and gestures express an action, and not simply some ready-made "internal reality'" (Lefebvre, 1991: 135). 
The gestures are humble and kind because they are trained to do so by their choreographers and parents. The children are given a rule book of do's and don'ts by their parents to gain popularity and a good name. There are hardly any traces of innocence or naivety in the child because he/ she is no more genuine or is not allowed to be so.

"You need to only watch a child to realize that whatever it says is intended to influence you, to obtain a specific result from you, and must therefore be understood terms of yourself, the moment in time and intention; it is the very essence of childhood: a weak being seeking to get results from stronger beings whom he sees as being terrible, grandiose, powerful... and ridiculous. (Lefebvre, 1991: 135).

The fact about children working in television industry is quite tricky as they are generally not considered as child labour. The main reason behind this may be because of the status of a theatre artist given to the children participating in a reality television show. This trend of using children in television shows has raised a number of issues relating to their rights, labour laws, the ethics of using children to boost ratings, the psychological impact on children participating in such shows and the morality of making them an object of voyeurism. The director's play is staged to manipulate the produced content and to enhance the child into a subject which yields rating points, thus forming an intentional image of the child. As an assistant director I was often instructed to talk friendly and convince the parents to (i) make their child emote on stage, (ii) make their child wear apt costumes according to the songs they dance to (including revealing costumes) (iii) manage to stay in the sets with the child until the shoot gets over (even if it takes late nights and early mornings). According to the programming crew, having a child or two in the show meant covering a whole group of prominent audiences.

Emotions and children are two strategic keys to increased rating points. But with the growing popularity of reality shows, the number of children made to perform on television has become quite evident. The performances include not only the on-stage, but also the off-stage performances that are often taught and practiced by parents. To bring an effective example to detail these 
characteristics, let me quote an example of my experience when working for a dance reality show that was meant for common public talents. There was a differently-abled (deaf and dumb) kid who participated in this show. This child was trained by a master who would choreograph and teach him all the intricacies of dancing. As the child got into the show, he instantly gained momentum by capitalising his special abilities into positives. But the sad part was that the mother played a strong role of manipulating the child's behaviour on and off the screen. During the shoot days, the child was made (taught) to personally approach every crew member. He was made to mark his presence by saluting and wishing with gratitude and also by falling on the feet of choreographers and celebrities who judge them on stage. Whenever the mother was called up on to the stage, she managed to cry; lamenting the disability of her child.

On the final day, as the child completed his performance there was an overwhelming reaction from the parent's side. The crew also witnessed how the mother prompted the child to cry on stage. The child was already instructed to shed tears after the performance to gain more sympathy. The innocent eleven year old tried acting as if he was weeping. This scene was a shock to the crew as we did not expect a deaf and dumb child to do this under the guidance of his parent. Here, the child was completely under the control of the mother and was well trained to portray himself in a manner that convinced the cast and crew of the show. Such parents fail to understand that the sympathy gaining activities that are taught to the child would inevitably affect the child. It could spoil the child's self-confidence and nurture complex emotions of self-pity and manipulative behaviours. As rightly said by Holland (2004), "Children are dependant, powerless and ignorant, which constructs the adults as independent, powerful and knowing".

To summarise, reality television is known for its undefined timings and non-regulated principles. Most of the time, two to four episodes are shot in a day which amounts to a continuous 16 to 20 hours of shoot and squeezes the energy out of the young participants. The child is forced to lose his/ her innocence, forget normality and sustain the portrayal for long periods that gradually becomes the child's original nature over a period of time proving 
hazardous to his / her own day to day life. There are various ways a child suffers and is exploited as a child artist: parental pressure, loss of innocence, victims of public imagery and stardom, nonconsent, race, class and caste discriminations in their everyday life.

\section{Parting Reflections}

This is an experimental paper that has intertwined analysing the conditions of child artists in reality televisions with the employment of the methodology of autoethnography. This study could not focus on more dimensions in analysing child artists in reality televisions due to restricted space and time, I have engaged with only a few dimensions in the present study. To summarise, I have given only a select band of reflections (not conclusions) that I attained through the journey of reality television production and autoethnography.

Tamil Reality television productions lack the ethical guidelines for dealing with child participants. There are no specific safety rules to be followed, no restrictions on practice time, and no regulations in content. As an entertainment for adults, Tamil reality television has been victimising a number of children in a very subtle process which is never brought out by insiders and outsiders. More than the often discussed points of education and health of the child artists, there is a largely unnoticed underlying danger of destructive psychological effects that taint the childhood and later adulthood of every child participant. I observed a state of depression and soreness in every child that I saw (and interviewed) during and after different stages of their reality show experience. Majority of the child artists being unable to escape the burden of their early fame, lead an empty and meaningless life after the expectations of their popularity are not met. The short termed temporary fame develops a long term illusion of heroic status that keeps them a prisoner of stardom; the seasonal limelight prolongs expectations of consistent attention which seldom occur. They become reified victims of public image, stardom, fairness bias, lost childhood and parental pressure.

As an autoethnographer, I am obliged to reflect on the significance of using autoethnography as a method of inquiry. This study 
wouldn't have been possible without my lived experiences in the production sets of reality televisions. "Many of us were drawn to a life of research by our lived experiences of emotional epiphanies that changed or deeply affected us.... Believe that these experiences strongly influence our perceptions and interpretations of other people's lives." (Ellis \&Bochner, 2016, p.50). Researches with one's own personal experience as a source is an important method in the current scenario, especially in social science researches which are done seeking social justice unlike the positivist quantitative science research where subjectification never happens. Critics of scientific traditions have argued for the abandonment of rationality, objectivity, and truth to move social science beyond a focus on method, toward the power of social research to have a moral effect (Bochner, 2001). There is no qualification required to gain a critical view on a societal practice, it's just the criticality that is required. With more autoethnographic research in the field of media production, there will be significant illumination on the cultural, spatial and labour issues. Just as the sociologist Max Horkheimer (1930's) described "a theory is critical insofar as it seeks to liberate human beings from the circumstances that enslave them" (Horkheimer, 2002), I see autoethnography working more as a theory than just a method as it brings the unquantifiable elements into existence through self-reflections, personal narrative and personal experiences.

\section{References}

Adams, T.E., Ellis, C. \& Jones, S.H. (2017). "Autoethnography": The International Encyclopedia of Communication Research Methods. Oxford University Press. Retrieved from: https:// doi.org/ 10.1002/ 9781118901731.iecrm0011

Andrejevic, M. (2008). Watching Television without Pity: The Productivity of Online Fans. Television \& New Media, 9(1), 24-46.

Biressi, A. \& Nunn, H. Ed. C Carter, L. Steiner, L. Mclaughlin (2013). Class, Gender and the Docusoap: The Only Way Is Essex. The Routledge Companion to Media \& Gender, pp.269-79.

Bhattacharjee, S. 2014. Sophisticated Work Done by Children is Child Labour: An Overview of Children Working in Industries. International Journal of Research in Humanities, Arts and Literature, 6 (2), 45-52. 
Bochner, A. P. (2000). Criteria against ourselves. Qualitative Inquiry, 6(2), 266-272.

Benjamin, W. (1969). Arendt, H. (Ed.). The Work of Art in the Age of Mechanical Reproduction. New York: Schock Books.

Clandinin, D. J., \& Connelly, F. M. (1994). Personal experience methods. In N. K. Denzin \& Y. S. Lincoln (Eds.), Handbook of qualitative research (413-427). London: Sage.

Cianci, C. (2008). Entertainment or Exploitation? Reality Television and the Inadequate Protection of Child Participants under the Law. Interdisciplinary Law Journal, Southern California, 18 (2), 363-394.

Devantier, T. (2006). Extraordinary Jobs in Entertainment. Infobase Publishers.

Ellis, C. (1991). Sociological Introspection and Emotional Experience. Symbolic Interaction. 14 (1), 23-50.

Ellis, C. \& Bochner, A. (2000). Autoethnography, Personal Narrative, Reflexivity: Researcher as Subject.

Ellis, C. (2004). A Methodological Novel about autoethnography. CA:Rowman Altamira

Ellis, C. (2007). Telling Secrets, Revealing lives: Relational Ethics in Research with Intimate others. Qualitative Inquiry, 13, 3-29.

Ellis, C., Adams, T.E. \& Bochner, A. (2011). Autoethnography: an Overview. Historical Social Research. 273-290

Ellis, C. \& Bochner, A. (2016). Evocative Autoethnography: Writing Lives and Tellin Stories. Taylor \& Francis.

Foucault, M. (1997). "The Birth of Biopolitics". Ethics, Subjectivity, and Truth: P. Rabinow and J.D. Faubion eds. New Press. (73-79)

Foucault, M. (2003). Lecture 11, 17 March 1976, Society Must Be Defended: Lectures at the College de France. Picador Press. (239-264)

Goldschmidt, W. (1977). Anthropology and the coming Crisis: An Autoethnographic appraisal. American Anthropologist, 293-308. https:// anthrosource. onlinelibrary.wiley.com/ doi/abs/ 10.1525/ aa.1977.79.2.02a00060

Greenhalgh, T. (2001). Storytelling Should Be Targeted Where it is known to have Greatest Added Value. Medical Education. 35 (9).

Hayano, D.M. (1979). Auto-ethnography: Paradigms, Problems, and Prospects. Human Organisation, 38, 99-104. https:// doi.org/ 10.17730/ humo.38.1.u761n5601t4g318v Accessed 18 April 2020.

Heider, K.G. (1975). What do people do? Dani Auto-ethnography. Journal of Anthropological Research, 31, 3-17. https:// www.journals. uchicago.edu/ doi/10.1086/jar.31.1.3629504

Hill, A. (2005). Book Review: Understanding Celebrity. International Journal of Cultural Studies, 8(3), 379-381. 
Holland, P. (2004). Picturing childhood: the myth of the child in popular imagery. London: I.B. Tauris.

Horkheimer, M. (2002). Critical Theory. New York: The Continuum Publishing Company.

Lazzarato, M. (2009). "Neoliberalism in Action: Inequality, Insecurity, and the Reconstitution of the Social". Theory, Culture \& Society. Vol. 26, no. 6.

Lefebvre, H. (1991).Critique of Everyday Life. Vol.1. London: Verso

Levey, H. 2010. Balloon boy "plus ei8ht?" children and reality television. Sage Publications, American Sociological Association, 9 (2), 72-75.

Murray, S. \& OulLette, L. (Ed.). (2004). Reality TV: Remaking Television Culture. (2nd ed.) New York University Press.

National Commission for Protection of Child Rights, 2010-2011. Guidelines to Regulate Child Participation in TV Serials, Reality Shows and Advertisements. 1-16.https:// mib.gov.in/ sites / default/files/pc7.pdf

O'Connor, J. (2008). The Cultural Significance of the Child Star. New York: Taylor \& Francis. Retrieved from: file:/// E:/References\%20\% 20 PDF/Research\%20Articles/Everyday\%20Life/[Jane_C_O'Connor]_Th e_Cultural_Significance_of_the(z-lib.org).pdf

Palmer, L. (2013). Sluts, Brats, and Sextuplets: The Dangers of Reality Television for Children and Teen. Popular Culture Association in the South, 36 (1), 123-143.

Parham, L.D. \& Fazio, L.S. (1997). Play in occupational therapy for children. St. Louis: Mosby

Pelia, R. (2004). A Methodology of the heart: Evoking Academic and Daily Life. Wallnut Creek, CA: Alta Mira Press.

Penzhorn, H. \& Pitout, M. (2007). A critical-historical genre analysis of reality television Communication, 33 (1), 62-76.

Reed-Danahay, D. (Ed.). (1997). Auto/Ethnography: Rewriting the self and the social. Oxford, UK: Berg.

Roberts, E. M. (2004). Through the Eyes of a Child: Representations of Blackness in Children's Television Programming. Race, Gender, and Class in Media, 11 (2), 130- 139.

Sparkes, A. C. (2000). Autoethnography and narratives of self: Reflections on criteria in action. Sociology of Sport Journal, 17, 21-43.

Venkatesh, S.P. (2020). Discipline, Control and Children in Tamil Reality Television. Deleuzian and Guattarian Approaches to Contemporary Communication Cultures in India. Singapore: Springer Nature.

Wall, S. (2006). An Autoethnography on Learning about Autoethnography. International Journal of Qualitative Methods 5(2).

Wayne, M. (2009). Marxism and Media Studies: Key Concepts and Contemporary Trends. South Asia: Aakar Books. 